Subject that makes the artist's own organism. The proof of this is that while talent copies nature, genius does not copy but produces works co-ordinate with nature, lending soul and life to the bodily thing* it represents, as in the personifications of nature in lyric poetry; and, as in the dramatic and pictorial expression of the emotions, giving body and object to the thoughts of the soul. The same soul that drew the gestures in Leonardo's Last Supper, etc., prompted those gestures in Leonardo's person, and organized Leonardo's nervous system for their execution.

The range of our author's anecdotes is very great, and his choice of them absolutely uncritical. He appears to hold for true anything which any one may ever have reported, the publications of the Psychical Research Society being almost the only source not drawn upon in his pages. Add to this his unchartered freedom of theorizing, and the result is of course completely 'unsatisfactory', although the book remains 'suggestive' enough. But in the present era of anarchy in these outlawed matters no one can be punished for any special sort of unsatisfactoriness in which he may prefer to indulge, so I say no more. Nevertheless between Mr. Lang's facility in leaving things unsettled, and Baron du Prel's facility in concluding them, it seems as if a better path might be found. Might not the earnest temper of science be combined somewhere with Du Prel's learning and the power of doubt of Lang? So far Mr. Myers's papers on the 'Subliminal Self' seem to have kept nearest to this ideal ; and both Lang's and Du Prel's books set off by contrast the superiority of his work.

W. J.

\title{
THE NERVOUS SYSTEM.
}

Die Nervenselle bei der Geburt und beim Tode an Alterschwdiche. C. F. HoDGe. Anatomischer Anzeiger, Bd. Ix. No. 23. Journ. of Physiol., vol. xvir. Nos. I and 2.

These studies have been made on men and bees. That the active tissues of the body represented by the glands, nerves, muscles, and blood should exhibit changes in their structure due to old age was long ago probable, from what was known of cell-activity. One after another such changes have been demonstrated and the present paper shows the differences in certain parts of the nervous system of very old bees as compared with those that have just hatched from the pupa; and between the cells of a child at birth and those of an old man dying at the age of 92 years. The differences are illustrated by figures. When in the latter case the spinal ganglion-cells of the man were compared with those from the child, taken as a standard, it was found 
that in the senile cells the volume of the nucleus was reduced to 64 per cent, that it was irregular in outline and shape, that the nucleolus was visible in but one tenth as many cells as in the child, and that while in the latter the cells were not at all pigmented, in the old man all of them had pigment, and in two thirds of them it was abundant. In the cerebellum it appeared that some of the Purkinje's cells were shrunken and that some perhaps had entirely disappeared. In the cerebrum no differences were determined, but in this locality the inquiry was not extensive. In the young bees the nerve-cells are smaller than in the aged ones (antennary ganglion), they have a large nucleus surrounded by a thin layer of eytoplasm, and are absolutely more numerous in the young than in the very old, in the proportion of 2.9 cells to 1. The senile cells have shrunken nuclei and the cytoplasm reduced to shreds, separated by large vacuoles. The gross changes in these cells for both men and bees are similar to changes found in the fatigued nerve-cells (bees and cats), but the absence of increased granulation and a deeper staining of the nuclei indicates that the chemical constitution of the cell has altered in the process of growing old. There are grounds for a close analogy between fatigue and senescence, and the differences in the nerve-elements doubtless depend on the fact that while fatigue is accompanied by the consumption of the stored materials in the cytoplasm, old age is characterized by a diminution not only of the stored materials themselves but in the power of restoration.

\section{A Microscopical Study of the Nerve-cell during Blectrital Stimulation.}

C. F. HodGr. Journal of Morphology, vol, IX. No. 3, x894.

The changes in the nerve-cell which Hodge bas been able to observe after electrical stimulation of the sensory nerves in the frog and cat; as the result of diurnal fatigue in birds and bees, and as an expression of old age in bees and man, have led him to attempt the direct observation of nerve-cells while they were being stimulated. The cells employed were those of the spinal and sympathetic ganglia of the frog. The method of observation consisted in removing symmetrical ganglia from the same animal and placing each ganglion on the stage of a microscope where its further changes could be followed. Both were enclosed in chambers and irrigated by a nutrient fluid. On one slide, however, wires had been laid, so that the cells there located could receive electrical stimulation. The two specimens were then examined from time to time and the nuclei in which the principal changes occurred were drawn and measured at regular intervals. The manipulation of such experiments, which were carried on anywhere from fifteen minutes to six days, was extremely difficult, and hence 
many variations were observed, doubtless due to lack of identity in the experimental conditions. If the stimulus is not strong enough to either paralyze or kill the cell in a short time, those changes which have been described as characteristic of fatigue were seen to occur in the nucleus and could be followed step by step. The result of direct observation gives, therefore, a full confirmation of the previous conclusions. At the same time a number of new and interesting facts were incidentally observed. The reactions of the cells were in general similar at all seasons of the year. In some cases (2) neither nuclei nor nucleoli of the nerve-cells could be seen, this peculiarity occurring both in winter and summer frogs. On stimulation the nuclei became faintly visible, but no nucleoli were observed. In some instances the cytoplasm became lighter and clearer and oil-droplets tended to disappear as the result of stimulation, but in the living cell vacuolation was not evident.

During stimulation some of the granules in the nucleolus were extruded into the nucleus, and very slight changes in the constitution of the nutrient fluid used for irrigation produced startling results. The addition of .I per cent of potassium tartrate to the solution of sodium chloride and calcium phosphate caused movements in the nucleolus; movements which were apparently amcboid. Under this treatment the nucleolus of the control cells only changed slightly in size, whereas the fragments of the stimulated nucleolus had all disappeared in thirty minutes. These facts are sufficient to show that the physiology of the nerve-cell is a suitable field for further study.

Beitrdge sur Kenntniss des Reichthums der Grosshirnrinde des Menschen an Markhaltgen Nervenfasern. THEODOR KaEs. Archiv f. Psychiatrie, Bd. xxv. Heft 3.

Ueber die Markhattigen Nervenfasern in der Grosshirnrinde des Menschen. Theodor Kars. Neurologisches Ceatralblatt, No. II, 1894.

The former of these papers is the more elaborate and the latter contains a corroboration of the observations there described. The investigation concerns the differences in the thickness of the entire cortex and its several layers in a youth of 18 as compared with a man of 38 years, attention being given to the several strata of tangential fibres and especially to those in the outer half of the cortex. The material consisted of both hemispheres of the youth and the right hemisphere of the man. A large number of samplesfrom every portion were taken, and the sections were stained by Wolter's method, which renders the 
medullated fbres black on a yellow ground. A naked-eye comparison of the sections thus prepared showed that nearly twice as many yellow, and one half as many yellow-gray and gray sections belonged to the youth, 25 to the man. Thus in a general way the cortex of the youth was found less blackened and consequently less well medullated than that of the man. The total thickness of the cortex was greatest in the man. The measurements taken at the summits of the gyri and the sides and bottom of the sulci show that the most marked increase in thickness occurred at the summit of the gyri. The convex surface of the brain underwent least increase, while the ventral and median surfaces showed the greatest change, that in the latter being most marked. The several fibre-layers do not exactly follow these changes in the total thickness; the outer layers of tangential fibres being most increased in thickness on the convex surface of the hemisphere where the cortex has gained the least in total depth. The most marked development of fibres in the man was found in the motor regions on the convex surface and in the temporal and occipital lobes about the centres for hearing and sight respectively. Particularly poor in fibres are the interior portion of the frontal lobes and the insula. Interesting is the observation that neighboring samples of the cortex may be quite differently developed. These facts, taken with observations by Vulpius along the same line, show a long-continued growth in the human cortex, a growth which quite escapes detection in the gross weighing of the encephalon and its parts, and yet one which certainly is in progress during the process of formal education, and can perhaps be influenced for good or ill by training. In itself the increasing medullation of the fibres is taken to mean a better organization of cortex by an increase in the functional connection between the cells, there slowly developing.

H. H. D.

The Microscopical Examination of the Human Brain. EDwIN GoodALL. London, Baillière, Tindall \& Cox, 1894. Pp. 186.

This little work is intended to give us a complete review of the methods of microscopical examination of the brain.

G. treats successfully the fresh method, the injection of cerebral blood-vessels, the hardening methods, fixation methods, imbedding, infiltration and section cutting, the staining methods, hardening combined vith staining, the clearing agents, and mounting media. He then adds an outline of the general plan of procedure in microscopical examination of the brain. The appendix contains the methods for museum specimens, and a valuable schedule of the equipment of a laboratory such as is needed in hospitals. A scheme for the post-mortem record 
is added, but no description of any special method to be followed in dissection.

Like most of the books of this kind it offers nothing from the point of view of a rational chemical or empirical explanation of the course of reasoning that led to the adoption of the rules given. We bave little more than a collection of prescriptions before us, with condensed in struction for their use.

The compilation of methods is very complete. The little work will not fail to have an important place in every neurological laboratory. It is to be hoped that the author will furnish soon a second part, containing the methods for examining spinal cord and nerves.

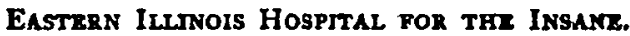

ADOLY MeYer.

\section{IDIOCY AND IMBECILITY.}

L'idiotie et limbécilite au point de vue nosographique. PaUz SollinR. Archives de Neurologie, vol. xxvi1. 33-38.

Recherckes cliniques et therapeutiques sur l'ipilepsie, l'hysterie et l'idiotie, etc. Coinpte rendu de 1892, vol. Xill. Bourneville. Paris, Bureaux du Progrès Medical, 1893. Pp. cxii +364.

L'idiotie, herédite et dégénertscence mentale, psychologie et education de

l'idiot. Jules Volsin. Paris, F. Alcan, 1893. Pp. 295.

Zur Ätiologic der Idiotie. Hermann Prper. Berlin, Fischer, 1893. Pp. 207.

Of late years the literature of idiocy has concerned itself chiefly with questions of classification, the differences of the different authors arising as usual from their various points of view. The first and perhaps the most important question at issue is whether idiocy is a condition distinct from imbecility or whether they are both merely degrees of one and the same affection. The latter is the view held by most writers in the past and at the present day, and it is to combat this that M. Sollier presents the paper mentioned above, supporting with clinical and pathological evidence a position he has already taken on psychological grounds in his well-known book 'Psychologie de l'idiot et de l'imbécile.' * In that work $M$. Sollier argued that idiocy and imbecility are, psychologically and socially, two distinct states, being united by a single common factor, viz., that their intelligence is inferior to the normal. Further, that if the idiot is to be considered as an

- Blbl de philosophie contemporaine. Paris, Alcan, IBgr. 